\title{
The Importance of Socio-Emotional Agency in Applied Games for Social Learning
}

Citation for published version (APA):

Prada, R. (2016). The Importance of Socio-Emotional Agency in Applied Games for Social Learning. In C. Vaz de Carvalho , P. Escudeiro, \& A. Coelho (Eds.), Serious Games, Interaction and Simulation. SGAMES 2016 (pp. 31-35). Springer. Lecture Notes of the Institute for Computer Sciences, Social Informatics and

Telecommunications Engineering https://doi.org/10.1007/978-3-319-51055-2_5

\section{DOI:}

10.1007/978-3-319-51055-2_5

Document status and date:

Published: 08/12/2016

Document Version:

Peer reviewed version

\section{Document license:}

CC BY-NC-SA

Please check the document version of this publication:

- A submitted manuscript is the version of the article upon submission and before peer-review. There can be important differences between the submitted version and the official published version of record. People interested in the research are advised to contact the author for the final version of the publication, or visit the DOI to the publisher's website.

- The final author version and the galley proof are versions of the publication after peer review.

- The final published version features the final layout of the paper including the volume, issue and page numbers.

Link to publication

\section{General rights}

Copyright and moral rights for the publications made accessible in the public portal are retained by the authors and/or other copyright owners and it is a condition of accessing publications that users recognise and abide by the legal requirements associated with these rights.

- Users may download and print one copy of any publication from the public portal for the purpose of private study or research.

- You may not further distribute the material or use it for any profit-making activity or commercial gain

- You may freely distribute the URL identifying the publication in the public portal.

If the publication is distributed under the terms of Article 25fa of the Dutch Copyright Act, indicated by the "Taverne" license above, please follow below link for the End User Agreement:

https://www.ou.nl/taverne-agreement

Take down policy

If you believe that this document breaches copyright please contact us at:

pure-support@ou.nl

providing details and we will investigate your claim.

Downloaded from https://research.ou.nl/ on date: 26 Apr. 2023 


\title{
The Importance of Socio-emotional Agency in Applied Games for Social Learning
}

\author{
Rui Prada \\ INESC-ID and Instituto Superior Técnico, Universidade de Lisboa \\ Avenida Professor Cavaco Silva, Taguspark - Edifício IST, 2744-016 Porto Salvo, Portugal \\ rui.pradadtecnico.ulisboa.pt
}

\begin{abstract}
Games have a great potential as learning tools, in particular, because they provide means for players to safely explore and fail, and because they promote personal emotional experiences. To be successful, games must present a good coverage and fidelity of the interaction experience regarding the target learning goals. In the case of learning of social skills, which is one prominent area of application of games, the use of Al characters with socioemotional agency has great potential value. These characters may increase the range of social situations that players can explore (coverage). However, in order to achieve that the Al characters need to be able to present good social behaviour (fidelity). Although, several examples of computational models to achieve this can be found, developing these models remains a challenging research question.
\end{abstract}

\section{$1 \quad$ Applied Games and Learning}

Games have been used for other purposes beyond entertainment for several years. For example, as tools to engage people in crowdsourcing tasks, e.g. ESP Game [1], for citizen science [2], e.g. Foldit [3], to motivate people to do more physical exercise, e.g. Exergames [4], to create awareness of some subjects, e.g. Darfur is Dying [5], and for training and learning, e.g. CellCraft ${ }^{1}$, DragonBox ${ }^{2}$, Treme-Treme ${ }^{3}[6]$.

\footnotetext{
${ }^{1} \mathrm{http}: / /$ www.carolina.com/teacher-resources/Interactive/online-game-cell-structurecellcraft-biology/tr11062.tr

${ }^{2}$ http://dragonbox.com/

${ }^{3}$ http://treme-treme.pt/

adfa, p. 1, 2011.
}

(C) Springer-Verlag Berlin Heidelberg 2011 
The use of games for learning is sustained in the strong connection between play and learning, noted in child development studies [7], an idea that was already discussed in the seminal work of John Locke and Jean-Jacques Rousseau in the XVII and XVIII centuries. In turn, learning has been regarded as an important activity in games for promoting fun. Following the Natural Funativity theory [8], which presents fun as a reward for learning, a game that has nothing to teach to a player will become boring and will, therefore, be abandoned.

The work of Clark Abt [9], in 1970, fostered the idea of having games directly presented as tools for learning. He coined the term serious games as games that have "an explicit and carefully thought-out educational purpose and are not intended to be played primarily for amusement". Abt argued for the development of new games taking learning goals as their main concern. Since then, serious games have grown as a research field and the term has evolved (commonly, referred now as applied games or games with purpose) to incorporate other serious applications besides education. Education and training are still, nevertheless, regarded as one of the application fields with most potential.

\section{Why Applied Games Work for Learning}

There are two main reasons why (good) applied games work as learning tools. First, because they enable practice, or, more importantly, because they support proactive exploration and failure. While playing, learners are motivated to explore the range of options presented in the game in the search for specific outcomes. Intended outcomes are not easily achieved, which means that players fail in the process until they achieve a good outcome. Games are good at supporting players recovering from those failures, because they do not imply major consequences in real-life. This means that players can safely fail. They do not fear failure too much and are, therefore, encouraged to explore the different options that the game offers and, for that reason, gain understanding of what works better for achieving different outcomes. The other main reason is, because games support the creation of personal emotional experiences, which have great impact in learning [10]. For example, note that you remember better the details of a city or country that you visited compared to the ones that you read about. This is due to the autobiographic emotional memories that were formed during your travel experi- 
ence. One can also build emotional memories by reading a book, however, the immersive nature of games and the fact that they give the control (and responsibility) of actions to the player is prone to deliver a stronger emotional experience. And the brain remembers better things that are more emotionally relevant [11]. Additionally, players have individual learning experiences while playing games as they explore options in the game in different ways.

Despite the learning potential of applied games, one can only learn about what the gameplay space affords. In other words, the learning experience is only achieved within the exploration space of the options presented by a game. For example, imagine learning how to play 8 ball pool through a digital game. A top down 2D game would support well learning the 8 ball pool rules, and some strategy and tactics, such as, position play. But, it would be limited for learning the execution of the shots, since the gameplay options regarding the angle of the force of the cue would be limited. To support better learning of the execution of shorts, the game would need to simulate the variables involved in the real world action in a better way. This implies an immersive $3 \mathrm{D}$ view, but also, and more importantly, direct controls over the cue using a first person perspective. Moreover, given the physical nature of the task, having force feedback on the cue would be important as well.

Note that despite the clear differences of the two games, we cannot claim that one would be better than the other. It depends on the target learning goals. In fact, having levels of detail in different areas of the learning domain in a game (or in game modes within a game) is important to support different focus in learning.

The effectiveness of an applied learning game depends on the coverage and fidelity of the game interaction space given the specific target learning goals. Coverage means that the game enables the player to explore options within all the dimensions that are relevant for the learning goals (e.g. the cue angle and force for learning how to perform shots in 8 ball pool), and fidelity means that the options available in each dimension are believable in the sense that the player can relate them to the real world action that he is trying to learn (e.g. the manipulation of the angle of the cue in the game is similar, in degrees of freedom and granularity, to the one performed with a real cue). 


\section{The Case of Learning Social Skills}

One of the prominent areas for applied games is learning of social skills [12]. To be effective in this case, the interaction space of the game needs to support exploration and failure of social actions. I argue that the use of Al characters with social emotional agency is crucial to achieve this. On one hand, Al characters increase the size of the social interaction space (increasing coverage) by supporting the generation of social behaviour based on the player interaction that does not need to be fully scripted beforehand. Thus, supporting a wider range of social situations for the player to explore. But, on the other hand, the Al characters need to be socially intelligent and believable to support the fidelity of the learning experience.

To develop Al characters with good social intelligence and believable behaviour is quite a challenging research problem. It implies developing characters that: act socially (i.e. taking others in consideration), according to social context, with socio-emotional states, and having social needs and social goals. Additionally, these characters need three major type of concerns: to understand others (e.g. developing Theory of Mind), to understand the social reality (e.g. social categories, moral values, norms) and to be able to adapt to different situations, including, learning how to deal with new situations. To deal with all this we need to develop computational models that address many different aspects of social behaviour, such as, group dynamics [13], social power [14], cultural behaviour [15], social importance [16], social relationships [17], interaction dynamics [18], social identity [19], personality [20] and social practices [21]. However, although we can find models with good results for particular aspects of social behaviour, it is not common to find models that are able to deal with many of the aspects at the same time. Hence, to integrate a comprehensive set social behaviour capabilities in a unique model remains a challenge.

\section{Acknowledgements}

The work presented here was supported by national funds through Fundação para a Ciência e a Tecnologia (FCT) with reference UID/CEC/50021/2013 and by the research project RAGE (Realising an Applied Gaming Eco-System) funded by the EU under the H2020-ICT-2014-1 programme with grant agreement no 644187. 


\section{References}

1. Von Ahn, L. and Dabbish, L.: "Labeling images with a computer game". In Proceedings of the SIGCHI conference on Human factors in computing systems, pp. 319-326. 2004. ACM.

2. Khatib, F., Cooper, S., Tyka, M. D., Xu, K., Makedon, I., Popović, Z., Baker, D. and Players, F.: "Algorithm discovery by protein folding game players. Proceedings of the National Academy of Sciences, 108(47), pp. 18949-18953. 2011.

3. Cohn, J. P.: “Citizen science: Can volunteers do real research?”. BioScience, 58(3), pp. 192-197. 2008.

4. Göbel, S., Hardy, S., Wendel, V., Mehm, F. and Steinmetz, R.: "Serious games for health: personalized exergames" . In Proceedings of the 18th ACM international conference on Multimedia, pp. 1663-1666, 2010. ACM.

5. Brown, J. G.: "Teaching about genocide in a new millennium." Social Education, 71(1), pp. 21. 2007.

6. Barreto, P., Prada, R., Santos, P. A., Ferreira, M. A., O'Neill, H. and Oliveira, C. S.: "Tremetreme - A serious game to teach children earthquake preparedness". In Proceedings of Videojogos 2014 - Sétima Conferência de Ciências e Artes dos Videojogos, Barcelos, Portugal. November 2014. Digital Games Lab, IPCA.

7. Vygotsky, L.S.: "Mind in society: The development of higher mental functions". 1978. Cambridge, MA: Harvard University Press.

8. Koster, R.: "Theory of fun for game design". 2013. O'Reilly Media.

9. Abt, C.: "Serious games". 1987. University Press of America.

10. Kolb, D. A.: "Experiential learning: Experience as the source of learning and development". 2014. FT Press.

11. Nelson, K.: "The psychological and social origins of autobiographical memory". Psychological Science, 4, pp. 7-14. 1993.

12. Pereira, G., Brisson, A., Prada, R., Paiva, A., Bellotti, F., Kravcik, M. and Klamma, R.: "Serious games for personal and social learning \& ethics: status and trends" Procedia Computer Science 15, pp. 53-65. 2012.

13. Prada, R. and Paiva, A.: "Teaming Up Human with Synthetic Characters". Artificial Intelligence, vol. 173 (1), pp. 80-103. 2009. Elsevier.

14. Pereira, G., Prada, R. and Santos, P. A.: "Conceptualizing Social Power for Agents". In Proceedings of IVA'2013 - 13th International Conference on the Intelligent Virtual Agents, Lecture Notes in Computer Science, Vol. 8108, pp. 313-324, Edinburgh, UK. 2013. Springer.

15. Mascarenhas, S., Dias, J., Prada, R. and Paiva, A.: "A Dimensional Model for Cultural Behaviour in Virtual Agents". Applied Artificial Intelligence, vol. 24 (6), pp. 552-574. 2010. Taylor \& Francis. 
16. Mascarenhas, S., Degens, N., Paiva, A., Prada, R., Hofstede, G. J., Beulens, A. and Aylett, R.: "Modeling culture in intelligent virtual agents: From theory to implementation". Autonomous Agents and Multi-Agent Systems. pp. 1-32. 2015. Springer.

17. Leite, I., Pereira, A., Mascarenhas, S., Martinho, C., Prada, R. and Paiva, A.: "The influence of empathy in human-robot relations". International Journal of Human Computer Studies, vol. 71 (3), pp. 250-260. 2013. Elsevier.

18. Pereira, A., Prada, R. and Paiva, A.: "Improving social presence in human-agent interaction" in proceedings of CHI'2014 - 32nd annual ACM conference on Human Factors in Computing Systems, pp. 1449-1458, Toronto, Canada. 2014. ACM.

19. Dimas, J., Lopes, P. and Prada, R.: “One for all, all for one: Agents with social identities". In Proceedings of CogSci'2013 - 35th Annual Meeting of the Cognitive Science Society, pp. 2195-2200, Berlin, Germany. 2013. CSS.

20. Prada, R., Ma, S. and Nunes, M. A.: "Personality in Social Group Dynamics". In Proceedings of International Conference on Computational Science and Engineering, vol. 4, pp. 607-612. 2009. IEEE.

21. Dignum, F., Dignum, V., Prada, R. and Jonker, C. M.: "A Conceptual Architecture for Social Deliberation in Multi-Agent Organizations: a position paper" International Journal of Multiagent and Grid Systems. vol. 11 (3), pp. 147-166. 2015. IOS Press. 